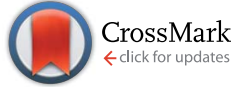

Cite this: J. Anal. At. Spectrom., 2015, 30, 1609

\title{
Evaluation of the analytical performances of a valve-based droplet direct injection system by inductively coupled plasma-atomic emission spectrometry $\dagger$
}

\author{
Kaori Shigeta, ${ }^{\text {a }}$ Yuki Kaburaki, ${ }^{\text {}}$ Takahiro Iwai, ${ }^{\text {b }}$ Hidekazu Miyahara ${ }^{\text {b }}$ \\ and Akitoshi Okino ${ }^{\mathrm{b}}$
}

\begin{abstract}
We have developed a sample introduction system using a magnetic valve type dispenser, named "droplet direct injection nebulizer (D-DIN)". In the case of the D-DIN, sample solution is directly injected as a single droplet or a series of droplets into the plasma. The droplet volume can be controlled across a wide range of droplet size from $700 \mathrm{pL}(110 \mu \mathrm{m})$ to $100 \mathrm{~nL}(580 \mu \mathrm{m})$ by changing the inner diameter of the nozzle tip, back pressure and valve open time. The D-DIN system additionally enables direct injection of cells contained in a droplet into the plasma. In this study, the droplet system was optimized, and droplet characterization and analytical performances by emission profiles were investigated. When the emission intensities of $15 \mathrm{~nL}$-volume droplets were measured by side-on observation, the detection limits of $\mathrm{Na}, \mathrm{Mg}$ and $\mathrm{Sr}$ were $20.3 \mathrm{pg}\left(1.35 \mu \mathrm{g} \mathrm{mL} \mathrm{L}^{-1}\right), 56.5 \mathrm{pg}\left(3.77 \mu \mathrm{g} \mathrm{mL}^{-1}\right)$ and $20.6 \mathrm{pg}\left(1.37 \mu \mathrm{g} \mathrm{mL}^{-1}\right)$, respectively. Finally, a single droplet containing yeast cells was directly introduced into ICP and the emission profile of Na was measured with a satisfactory signal to noise ratio.
\end{abstract}

Received 9th December 2013

Accepted 1st May 2015

DOI: $10.1039 / c 3 j a 50382 h$

www.rsc.org/jaas
Scott Tanner's group from the University of Toronto has shown for the first time a single cell analysis by using a homemade mass spectrometric cytometer (MSC) ${ }^{5}$ based on an inductively coupled plasma mass spectrometry (ICP-MS). In the work of Scott Tanner's group, the cells were detected indirectly in an immunoassay by the use of a metal labeled antibody. ${ }^{6}$ For sample introduction a conventional micro-concentric nebulizer in a desolvation system was applied. ICP-MS used for the MSC is based on a very specific time of flight instrument, which only allows the measurement of all elements above $100 \mathrm{Da}$. Thus it has not yet been applied to measure the natural composition of essential elements and metals in single cells. The direct labelfree analysis of single cells by ICP-MS has been first reported by Sam Houk's group. ${ }^{7}$ They measured the signal of $\mathrm{U}$ incorporated intrinsically into Bacillus subtilis using a micro-concentric nebulizer and operated the ICP-sector field mass spectrometer (SFMS) with an integration time of $4 \mathrm{~ms}$ to investigate the behavior of single cells and observed $\mathrm{U}^{+}$spikes for intact bacteria. Recently, a single particle methodology using a glass concentric nebulizer was applied to algae, ${ }^{8}$ yeast $^{9}$ and nanoparticles. ${ }^{\mathbf{1 0}}$

On the other hand, monodisperse droplet generators have been used to observe the production of atoms and ions for flames and plasmas. Hieftje et al. developed a system to generate droplets on demand by mechanically disturbing a liquid stream transported through a capillary. ${ }^{\mathbf{1 1}}$ The developed system was applied for the observation of atoms and ions for
${ }^{a}$ Research Institute for Environmental Management Technology, National Institute of Advanced Industrial Science and Technology (AIST), 16-1 Onogawa, Tsukuba, Ibaraki 305-8569, Japan. E-mail: kaori.shigeta@aist.go.jp; Fax: +81 29861 8308; Tel: +81298618336

${ }^{b}$ Tokyo Institute of Technology, Department of Energy Sciences, 4259 Nagatsuta, Midori-ku, 226-8502 Yokohama, Japan

$\dagger$ Electronic supplementary information (ESI) available. See DOI: 10.1039/c3ja50382h 
flames. For injection of individual droplets, and monodispersed and isolated droplets into an ICP, French et al. designed a monodisperse dried microparticulate injector (MDMI). ${ }^{12}$ This system consists of a piezoelectrically driven micro-pump, the flow rate of which can be varied by utilizing an appropriate variable-frequency square wave pulse generator from a single droplet (e.g., $57 \mu \mathrm{m}$ diameter droplet size, $0.1 \mathrm{~nL}$ diameter droplet volume) up to $6000 \mathrm{~Hz}\left(0.58 \mu \mathrm{L} \mathrm{s}{ }^{-1}\right) .{ }^{12}$ Olesik et al. reported for the first time spatially and temporally resolved measurements of emission intensities using a MDMI. ${ }^{13}$ Emission profiles were measured from a single droplet, and its heights and peak areas had a relative standard deviation of 1$6 \%$. Groh et al. applied a commercial piezoelectric droplet generator to ICP-AES to investigate desolvation and atomization in an ICP. ${ }^{14}$

In the last couple of years, micro-droplet generators ( $\mu \mathrm{DGs}$ ) are becoming popular for the sample introduction system in ICP-MS. Niessen et al. have developed a home-built aerosol generator named "droplet on demand" based on a modified thermal inkjet cartridge. ${ }^{15}$ In our previous paper ${ }^{\mathbf{1 6 , 1 7}}$ we have optimized a micro-droplet generator ( $\mu \mathrm{DG}$ ) for sample introduction into an ICP-SFMS, which was also applied in the work of Gschwind et al. ${ }^{18}$ and Franze $e t a l .{ }^{19}$ for analysis of single metallic nanoparticles. We have shown for the first time that semi-metals and metals were investigated in single cells by using an ICP-SFMS with high time resolution. ${ }^{17}$ However, some problems related to this application still remain unanswered. The first problem is that cells might be destroyed during the high pressure shock waves produced for droplet generation. Exploding cells in the tip capillary would cause memory effects. The second problem is that clogging and the trajectory errors occur when the droplets containing a cell with several tens of $\mu \mathrm{m}$ in diameter are injected. It would be a rather limitation because a typical size of biological cells commonly used in experimental biology ranges from a few $\mu \mathrm{m}$ to several tens of $\mu \mathrm{m}$ in diameter. Fortunately, these have not yet been observed and can be related to the fact that the yeast cells used here are small enough (about $4 \mu \mathrm{m}$ ) and robust. ${ }^{17}$ For stable droplet injection containing a cell, the droplet diameter must be optimized to fit the cell diameter but a piezotype dispenser generates only a similar size of droplet at the nozzle tip diameter. In addition, it is hard to change a nozzle tip because a glass capillary with a nozzle tip is surrounded by a piezo-actuator. The fact also makes maintenance difficult when a capillary is clogged.

Taking all these into consideration, we developed a new sample introduction system using a magnetic valve type dispenser named droplet direct injection nebulizer (D-DIN) system..$^{20,21}$ In our previous work, the D-DIN system was applied to the ICP measurement system, and the emission intensities of the analyte were measured from droplets containing a sample solution. However, it was difficult to introduce the droplets into the centre of the plasma, and emission intensities were unstable in some cases. The present work has three main goals: (i) to improve the stability of droplet injection into the plasma, (ii) to show droplet characteristics and analytical performances such as signal intensity, precision and LODs from emission profiles, and (iii) to present a principle experiment of direct injection of a high amount of cell.

\section{Experimental}

\section{Reagents and samples}

The analytical performance of the D-DIN-ICP-atomic emission spectrometer (AES) was evaluated using a multi-element solution prepared from standard solution $\left(100 \mu \mathrm{g} \mathrm{mL} \mathrm{m}^{-1} \mathrm{Na}, \mathrm{Mg}\right.$, and $\mathrm{Sr}$, Kanto Chemical Co., Inc., Japan). Standard solution was diluted using ultra-pure water $\left(>18.4 \mathrm{M} \Omega \mathrm{cm}^{-1}\right.$ ) (Japan Millipore K.K., Tokyo, Japan). Sensitivity tuning of the D-DIN-ICP-AES was also conducted using the same multi-element solution. Dry yeast (Oriental yeast Co., Ltd, Tokyo, Japan) was used for direct injection of cells. To determine the concentration of yeast cells, dry yeast was digested with nitric acid (70\%) and hydrogen peroxide (30\%) (both were of electronic laboratory grade, Kanto Chemical Co., Inc., Japan). Samples of standard calibration were prepared by diluting a standard solution of $\mathrm{Na}\left(1000 \mu \mathrm{g} \mathrm{mL}{ }^{-1}\right.$; AAS grade, Kanto Chemical Co., Inc., Japan) with ultra-pure water.

\section{Elemental analysis of digested yeast samples}

To determine the total $\mathrm{Na}$ in yeast cells, $1.00 \mathrm{~g}$ of yeast sample was digested using a microwave oven (Multiwave 3000, PerkinElmer Japan Co., Ltd, Yokohama, Japan) after the addition of $20 \mathrm{~mL}$ nitric acid and $0.8 \mathrm{~mL}$ hydrogen peroxide. When samples were completely digested, indium was added to a final concentration of $50 \mathrm{ng} \mathrm{mL^{-1 }}$ for use as an internal standard, and the weight was adjusted to $100 \mathrm{~mL}$ (a dilution factor of 100) using ultra-pure water. Na was determined using an ICP-MS instrument (ELAN DRC-e, PerkinElmer Japan Co., Ltd, Yokohama, Japan), equipped with a conventional nebulizer (conical nebulizer $1 \mathrm{~mL} \mathrm{~min}^{-1}$, Glass Expansion, West Melbourne, VIC, Australia).

\section{Direct injection of standard solution and yeast cells using a D- DIN-ICP-AES}

For direct injection of standard solution, $10 \mu \mathrm{g} \mathrm{mL}{ }^{-1} \mathrm{Na}, \mathrm{Mg}$ and $\mathrm{Sr}$ standard solution was prepared by diluting a multielement solution using ultra-pure water. For direct injection of yeast cells, $500 \mathrm{mg}$ of dry yeast was diluted with ultra-pure water up to $50 \mathrm{~mL}$ (a dilution factor of 100). In order to minimize any alternation of yeast cells, yeast samples were diluted before analysis. The number of yeast cells in a single droplet was calculated from the concentration of yeast cells in the diluted yeast sample solution. The concentration of yeast cells was counted by using a cell counting plate and a microscope.

\section{Instrumentation}

\section{Droplet direct injection nebulizer (D-DIN) system}

The same setup of the D-DIN system in our previous paper ${ }^{21}$ was used to generate droplets. Fig. 1 shows the schematics of the DDIN system. A dispenser device (MJ-020 Standard Type, Mect Corporation, Osaka, Japan), which consists of a dispenser head equipped with a magnetic valve, control unit, and sample solution 


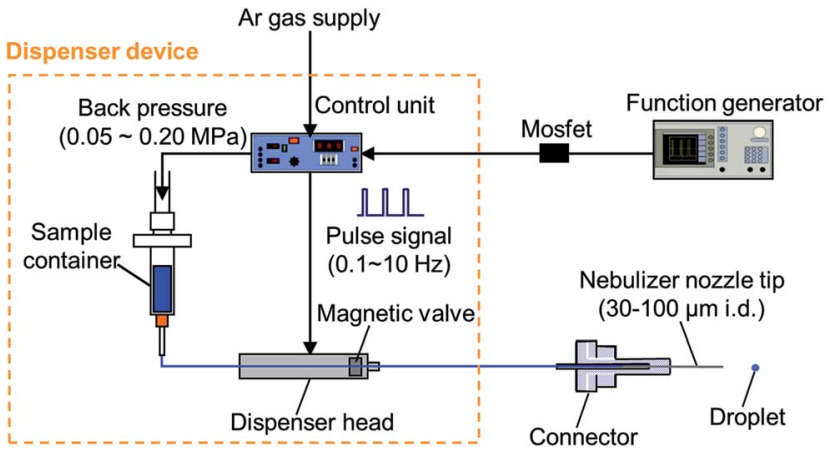

Fig. 1 Schematic of the droplet direct injection nebulizer (D-DIN).

container, was used as a droplet dispenser. The following parameters affected the droplet volume: applied back pressure $(<0.15 \mathrm{MPa})$ and valve open time $(0.04-10 \mathrm{~ms})$, controlled by the control unit. While a back pressure (0.001-0.200 MPa) was applied to the sample container, the sample solution was transported to the dispenser head, and injected by opening the magnetic valve with a short pulse. The pulse was provided by a function generator (AFG3102, Tektronix Inc., Tokyo, Japan), and transmitted to the control unit through a metal-oxide-semiconductor field-effect transistor (Mosfet) (ZVNL 120A, Diodes Inc., Taipei, Taiwan) used for amplifying and switching electronic signals. The number of droplets introduced could be controlled within a range from a single droplet to 5000 droplets per s. However, droplet introduction frequencies were set from 0.1 to $10 \mathrm{~Hz}$ during experimental investigation to avoid blinking and extinction of plasma. In this study, stainless steel tips (30, 50, $100 \mu \mathrm{m}$ i.d., $30 \mathrm{~mm}$ long, Mect Corporation, Osaka, Japan) and a fused-silica tip (30 $\mu \mathrm{m}$ i.d., 500 mm long, New Objective, Inc., Woburn, USA) were used as a nebulizer nozzle tip to reduce the droplet volume and to obtain fine droplets without droplet satellites. The silica tip was cut to 15 mm using a diamond-blade cleaving tool.

The velocity as the mean value of moving distance was measured by taking photographs with a high-speed video camera (500 flames $\mathrm{s}^{-1}$, MotionScope, Redlake MASD Inc., San Diego, CA, USA) every $2 \mathrm{~ms}$.

\section{Design of ICP-torch for the D-DIN}

An ICP-torch designed for the D-DIN system ${ }^{21}$ was modified for more stable transportation of the droplet. A design of the ICPtorch is described in Fig. 2. The torch had a three-layered tube structure and was made from quartz glass. The nebulizer nozzle tip was directly mounted onto the ICP torch using a laboratory design connector. In this study, a connector and spacer made from polytetrafluoroethylene (PTFE) were designed additionally to distribute the carrier gas through the centre of the spacer if necessary. The carrier gas flow in the inner tube is focused by the spacer, and it enables the droplet to be introduced into the centre of the plasma. The plasma gas is introduced into the middle layer from a tangential direction through the gas inlet, and the auxiliary gas is not needed for this torch. In the outer layer, the cooling gas is introduced, and is exhausted in the axial direction cylindrically around the plasma.

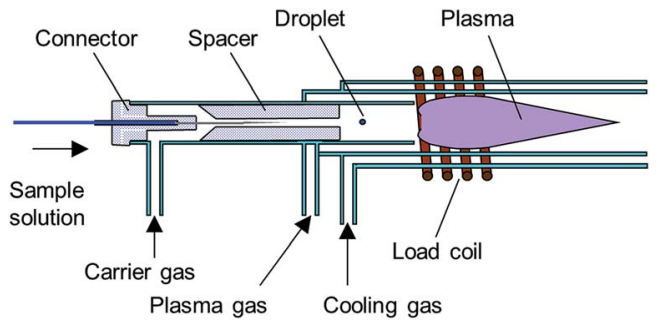

Fig. 2 ICP-torch for the droplet direct injection nebulizer (D-DIN) system.

In addition, the torch has two significant differences from a conventional Ar-ICP torch: (1) a smaller plasma gas inlet which creates a higher initial gas velocity and (2) a shorter distance between the plasma gas inlet and the plasma generation region which prevents a reduction in vortex flow velocity. ${ }^{22-26}$ The torch has the advantage that a stable Ar ICP can be generated from 200 to $1400 \mathrm{~W}$ RF power with a plasma gas flow rate of 3 to $15 \mathrm{~L}$ $\min ^{-1}$ and a cooling gas flow rate of $20 \mathrm{~L} \mathrm{~min}{ }^{-1} \cdot{ }^{25,26}$ In this study, the ICP was operated with a RF power of typically $1000 \mathrm{~W}$ and a plasma gas flow rate of 13 to $15 \mathrm{~L} \mathrm{~min}^{-1}$, and cooling gas was used to avoid the torch melting when the radio frequency wave (RF) power was higher than $1000 \mathrm{~W}$. The other experimental facilities of the ICP source, such as an RF generator, impedance matching network and gas introduction, have been described in previous papers. ${ }^{22,26}$

\section{Spectrometer and data acquisition}

The optical detection system consists of a spectrometer (500 $\mathrm{mm}$ focal length, $0.0270 \mathrm{~nm}$ resolution, Czerny-Turner) with a photoelectron multiplier (PMT) (R928, Hamamatsu Photonics Co., Ltd, Shizuoka, Japan). The spectral emission from the excited atoms was imaged using a quartz lens $(f=101.7 \mathrm{~mm}$, aperture: $40 \mathrm{~mm}$ ) onto a fibre, and was introduced to the entrance slit of a monochromator with a photomultiplier. The experimental arrangement is shown in Fig. I (ESI $\dagger$ ). In the case of side-on observation, the emission intensity was measured at a position of $0 \mathrm{~mm}$ above the load coil (A.L.C.). The lens was set

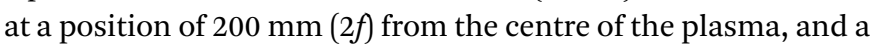
one-to-one image was focused at a position of $200 \mathrm{~mm}(2 f)$. In the case of end-on observation, the lens was set at a position of $300 \mathrm{~mm}(3 f)$ from a position of $0 \mathrm{~mm}$ A.L.C., and a half image was focused at a position of $150 \mathrm{~mm}(3 / 2 f)$. The alignment was performed by the adjustment of the imaging of ICP and the optical fibre to the maximum peak height of the analyte in multi-element solution. The photomultiplier signal was digitized and stored using a digital storage oscilloscope (TDS-680B, Sony/Tektronix Corp., Tokyo, Japan). A time resolution of $40 \mu \mathrm{s}$ was used to detect transient emission signals from a single droplet. The sample rate was $25 \mathrm{kHz}$.

\section{Results and discussion}

\section{Characteristics of droplets}

A piezo-based droplet dispenser has been applied for analysis of selenized yeast cells. ${ }^{17}$ However, as described earlier, there still 
remain two main problems to be resolved: (i) cell damage from piezoelectric shock waves; (ii) clogging and the trajectory errors occur by injection of a cell with several tens of $\mu \mathrm{m}$ in diameter. In the D-DIN system, a valve-based droplet dispenser is used, and does less damage to cells. Moreover, the nebulizer nozzle tip is easily exchangeable, and the variety of sizes in the nozzle tips can be chosen to fit to the cellular size. The parameters of sample introduction conditions-the nebulizer nozzle tip inner diameter, back pressure, and magnetic valve opening time and droplet introduction frequency-can be changed. The droplet volume as a function of the parameters was described in our previous paper. ${ }^{21}$ The volume and the diameter of the droplet were calculated from the density of water $\left(0.998 \mathrm{~g} \mathrm{~mL}^{-1}\right.$ at $\left.20^{\circ} \mathrm{C}\right)$ and the mean mass of a single droplet. The mean mass of a single droplet was calculated from a mass of 1200 droplets. A threshold pressure of $0.05 \mathrm{MPa}$ was required for stable droplet injection. Using this system, the droplet volume was changed from $700 \mathrm{pL}(110 \mu \mathrm{m})$ to $100 \mathrm{~nL}(580 \mu \mathrm{m})$. In the case of $700 \mathrm{pL}$ $(110 \mu \mathrm{m})$, the droplet volume, nozzle tip inner diameter, back pressure and valve time were set at $30 \mu \mathrm{m}, 0.02 \mathrm{MPa}$ and $0.5 \mathrm{~ms}$.

The sample droplet should be introduced linearly into the plasma. However, the trajectory of the droplet would be shifted considerably if its ejection speed is too low. Thus, the droplet velocity as a function of back pressure at various valve open times was evaluated (Fig. 3(a)). When the nozzle tip diameter was $100 \mu \mathrm{m}$ i.d., the droplet velocity increased from 0.55 to $14 \mathrm{~m}$ $\mathrm{s}^{-1}$ with a corresponding increase in back pressure. On the other hand, the droplet velocity was not altered by changing the valve open time. Next, the droplet velocity as a function of back pressure at various nozzle tip diameters was measured (Fig. 3(b)). The valve open time was set at $0.5 \mathrm{~ms}$. The droplet velocity increased from 2.5 to $16 \mathrm{~m} \mathrm{~s}^{-1}$ with a corresponding increase in back pressure. There were no marked changes in the nozzle tip diameter. Based on these results, it was concluded that the velocity of droplets can be controlled by the back pressure alone. The sample droplet velocity obtained using a typical nebulizer system and DIHEN is $5.3 \mathrm{~m} \mathrm{~s}^{-1}$ and $30-40 \mathrm{~m}$ $\mathrm{s}^{-1}$, respectively. Therefore, the D-DIN allowed samples to remain in the plasma for a longer time. The velocity could be increased by a carrier gas flow around the droplet.

\section{Observation of emission profiles from water droplets}

In the D-DIN system, as discussed earlier, the droplet volume was changed from $700 \mathrm{pL}(110 \mu \mathrm{m})$ to $100 \mathrm{~nL}(580 \mu \mathrm{m})$ but the droplet sizes are larger than those generated from the piezobased droplet dispenser. Thus, emission profiles were observed by introducing droplets generated from ultra-pure water. For droplet conditions, the nozzle tip inner diameter, back pressure and valve open time were set at $100 \mu \mathrm{m}, 0.05$ MPa and $0.5 \mathrm{~ms}$, respectively, and the volume of the droplet was $5.5 \mathrm{~nL}(220 \mu \mathrm{m})$. The droplet introduction frequency was $10 \mathrm{~Hz}$. For plasma conditions, the RF power and Ar gas flow were $1000 \mathrm{~W}$ and $14 \mathrm{~L} \mathrm{~min}^{-1}$, respectively. For the spectroscopy experiment, the argon atomic line (Ar I $425.11 \mathrm{~nm}$ and $\mathrm{Ar}$ I $426.62 \mathrm{~nm})$ and $\mathrm{H}_{\beta}$ line $(486.13 \mathrm{~nm})$ were measured by sideon observation. Fig. 4 shows the Ar atomic line (Ar I 425.11 (a) Various valve open time

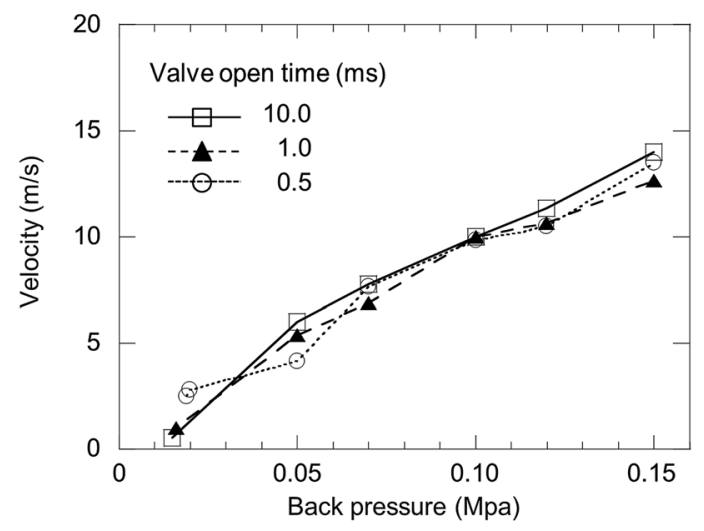

(b) Various nozzle diameter

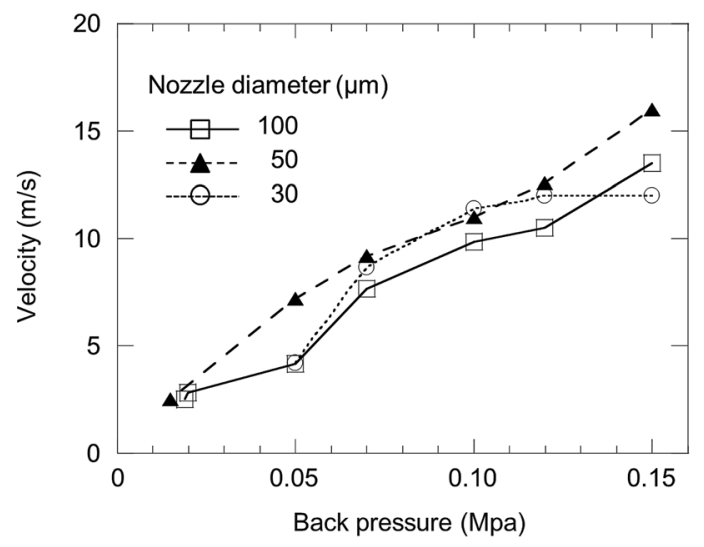

Fig. 3 Droplet velocity as a function of back pressure at (a) various valve open times: 0.5, 1.0 and $10 \mathrm{~ms}$ and (b) various nozzle diameters: 30,50 and $100 \mu \mathrm{m}$.

$\mathrm{nm}), \mathrm{H}_{\beta}$ line (486.13 nm) and Ar excitation temperature with droplet injection. The excitation temperature of $\mathrm{Ar}$ was calculated from the emission intensities of Ar I $425.11 \mathrm{~nm}$ and

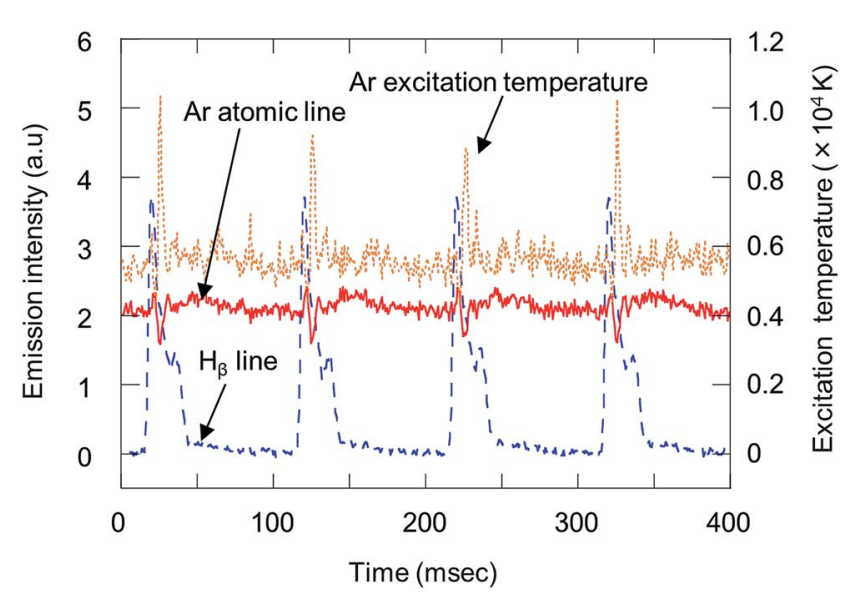

Fig. 4 Emission profiles of the Ar atomic line (Ar I $425.11 \mathrm{~nm}$ ), $\mathrm{H}_{\beta}$ line $(486.13 \mathrm{~nm})$ and Ar excitation temperature with injection of droplets generated from ultra-pure water. Emission intensities were observed by side-on observation (RF power, $1000 \mathrm{~W}$; droplet volume, $5.5 \mathrm{~nL}$ $(220 \mu \mathrm{m})$; droplet introduction frequency, $10 \mathrm{~Hz}$ ). 
$426.62 \mathrm{~nm} .{ }^{27}$ The droplets were injected at 0, 100, 200 and 300 ms. There was a fixed time lag between the timing of sample injection and detection of the $\mathrm{H}_{\beta}$ line. This delay was related to the time the droplets required to reach the plasma and become ionized after sample injection. The $\mathrm{H}_{\beta}$ line was increased at the same frequency of droplet injection. With an increase of $\mathrm{H}_{\beta}$ line, Ar excitation temperature decreased momentarily. This suggested that the population density of the excited Ar atoms decreased due to the desolvation of a droplet in the plasma. In addition, the excitation temperature overshot the value achieved before droplet injection. This effect might be due to the better heat conductivity caused by hydrogen. ${ }^{28}$

Fig. 5 shows variation in the emission profile of the $\mathrm{H}_{\beta}$ line as a function of RF power, valve open time and back pressure. In Fig. 5(a), for droplet conditions, the nozzle tip diameter, backpressure and valve open time were $100 \mu \mathrm{m}, 0.05 \mathrm{MPa}$ and 0.5 $\mathrm{ms}$, respectively, and the droplet volume was $5.5 \mathrm{~nL}(220 \mu \mathrm{m})$. The emission intensities were measured by side-on observation. When the RF power was $1000 \mathrm{~W}$, the emission intensity almost reached a plateau. In Fig. 5(b) and (c), the RF power was set at $1000 \mathrm{~W}$. Emission intensities increased with increasing valve open time and back pressure. The droplet volume at a valve open time of $0.5,2,5$ and $10 \mathrm{~ms}$ was $5.5,12,27$ and $51 \mathrm{~nL}$, respectively, and the droplet volume at a back pressure of 0.04 , 0.05, 0.07 and 0.10 MPa was 5.0, 5.5, 6.5 and 7.1 nL, respectively. However, the emission intensity did not proportionally increase with the droplet volume. This showed that the $\mathrm{H}_{\beta}$ line was not completely excited due to the large droplet volume.

\section{Atomization of elements contained in droplets}

To investigate the atomization of elements in droplets with carrier gas flow, droplets containing $\mathrm{Na}$ standard solution were introduced into plasma and measured by end-on observation. To avoid the spacer mounted on ICP-torch melting, the RF power was set at $700 \mathrm{~W}$. For droplet conditions, the nozzle tip inner diameter, back pressure and valve open time were $50 \mu \mathrm{m}$, $0.038 \mathrm{MPa}$ and $2 \mathrm{~ms}$, respectively, and the droplet volume was $4.7 \mathrm{~nL}(210 \mu \mathrm{m})$. A sample solution of $10 \mu \mathrm{g} \mathrm{mL}{ }^{-1} \mathrm{Na}$ standard solution was used. Fig. 6 shows the emission profile of the sodium atomic line $(588.99 \mathrm{~nm})$ and $\mathrm{H}_{\beta}$ line $(486.13 \mathrm{~nm})$ by endon observation, as a function of carrier gas flow rate $(0-0.8 \mathrm{~L}$ $\left.\min ^{-1}\right)$. At $0.4 \mathrm{~L} \mathrm{~min}^{-1}$ of carrier gas flow, a better peak shape was observed. The start of desolvation can be taken from the rising of the $\mathrm{H}_{\beta}$ emission. After the $\mathrm{H}_{\beta}$ intensity achieved its maximum, the sodium atomic line intensity increased. Atomization of sodium started after the end of desolvation, which can be seen from the decrease of $\mathrm{H}_{\beta}$ emission intensity. The duration for desolvation was then about $9 \mathrm{~ms}$, and is relatively long due to the large droplet volume compared to the sample residence time in the plasma. To achieve effective analysis of the droplet sample, we currently developed an injection gas heating system ${ }^{29}$ based on the desolvation system as described before. ${ }^{17,18}$ It is expected that the duration for desolvation would be shorter by applying the injection gas heating system to the D-DIN. (a) RF power

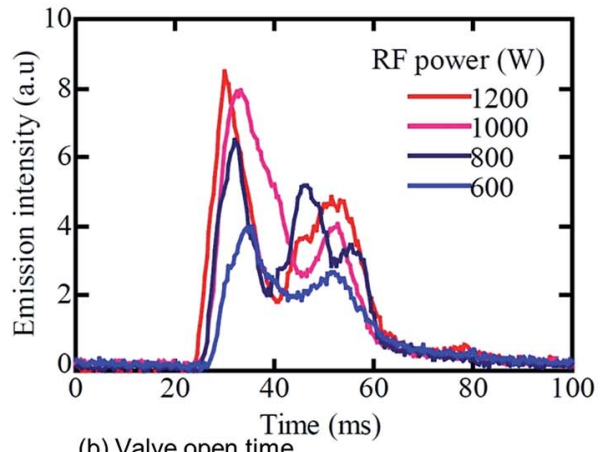

(b) Valve open time

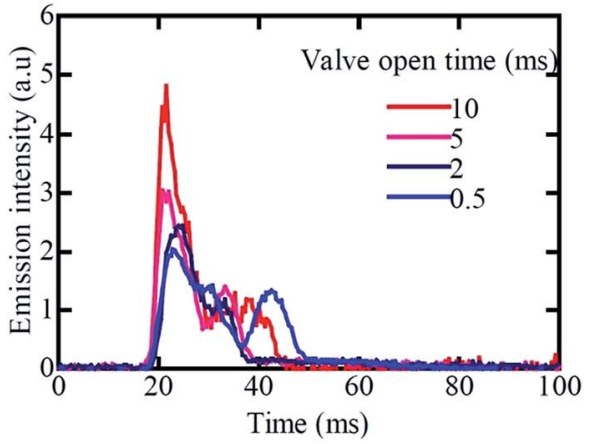

(c) Back pressure

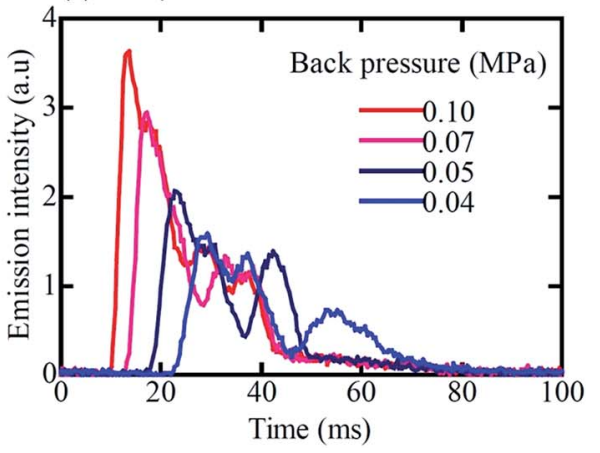

Fig. 5 Emission profiles of the $\mathrm{H}_{\beta}$ line $(486.13 \mathrm{~nm}$ ) as a function of (a) RF power, (b) valve open time, and (c) back pressure with injection of droplets generated from ultra-pure water. The RF power is $1000 \mathrm{~W}$. The droplets were injected basically under the following conditions: nozzle tip diameter, $100 \mu \mathrm{m}$; back pressure, $0.05 \mathrm{MPa}$; valve open time, $0.5 \mathrm{~ms}$. Emission intensities were observed by side-on observation.

\section{Evaluation of analytical performances of the D-DIN-ICP-AES}

Analytical performances of the D-DIN-ICP-AES, such as intensity, precision and LODs, were investigated. For this experiment, a fused-silica tip was used as a nebulizer nozzle tip. In the case of a fused silica tube, it is possible to generate droplets reproducibly due to the elaborate edge of the tip. The fused silica tube was cut to $15 \mathrm{~mm}$ to generate smaller droplets. The nozzle tip diameter, back pressure and valve open time were 30 $\mu \mathrm{m}$ (silica tip), 0.10 MPa and $2.0 \mathrm{~ms}$, and the droplet volume was $15 \mathrm{~nL}(300 \mu \mathrm{m})$. The RF power was $700 \mathrm{~W}$. The carrier gas flow rate was $0.4 \mathrm{~L} \mathrm{~min}^{-1}$, which was optimized in the previous section. Fig. II (ESI $\dagger$ ) shows the emission profiles of Na I 588.99 $\mathrm{nm}, \mathrm{Mg}$ II $280.27 \mathrm{~nm}$ and Sr II $407.77 \mathrm{~nm}$, with $10 \mu \mathrm{g} \mathrm{mL}{ }^{-1} \mathrm{Na}$, 

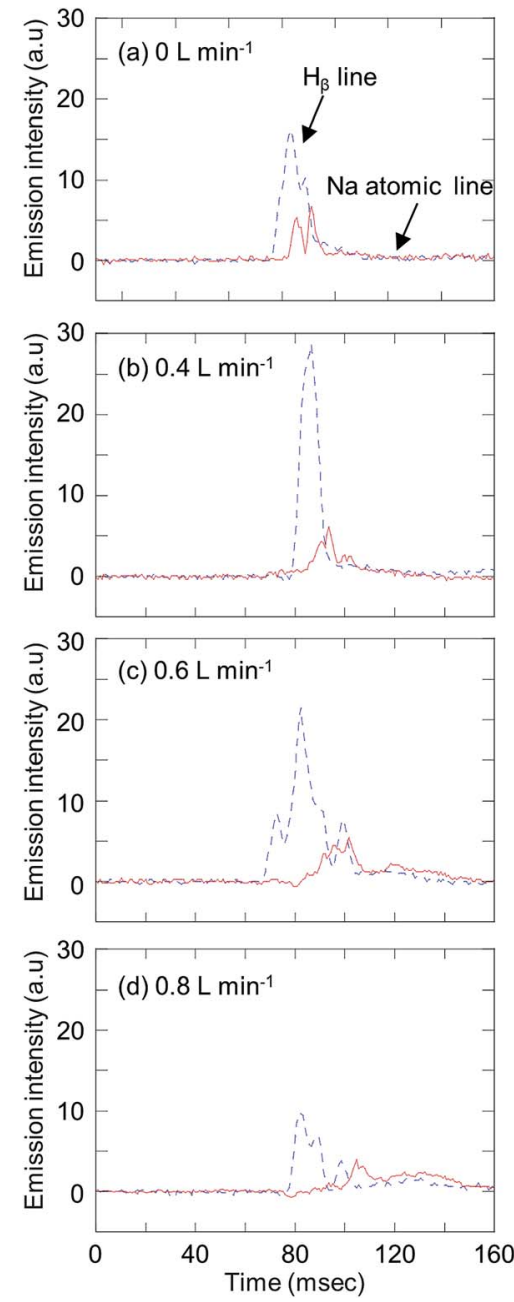

Fig. 6 Variation in emission profiles of the $\mathrm{Na}$ atomic line ( $\mathrm{Na}$ I 588.99 $\mathrm{nm}$ ) and $\mathrm{H}_{\beta}$ line $\left(486.13 \mathrm{~nm}\right.$ ) with a carrier gas flow of (a) $0 \mathrm{~L} \mathrm{~min}^{-1}$, (b) $0.4 \mathrm{~L} \mathrm{~min}-1$, (c) $0.6 \mathrm{~L} \mathrm{~min} \mathrm{~m}^{-1}$, and (d) $0.8 \mathrm{~L} \mathrm{~min}-1$, with injection of droplets generated from $10 \mu \mathrm{g} \mathrm{mL}^{-1} \mathrm{Na}$ standard solution. Emission intensities were observed by end-on observation (RF power, $700 \mathrm{~W}$; droplet volume, $4.7 \mathrm{~nL}(210 \mu \mathrm{m}))$.

$\mathrm{Mg}$ and $\mathrm{Sr}$ standard solution. Emission intensities were measured by side-on observation. Emission signals increased with the introduction of sample solution using the D-DIN. As it took some seconds to stabilize the background signal after injection of a droplet, the peak widths of $\mathrm{Na}, \mathrm{Mg}$, and $\mathrm{Sr}$ at $80 \%$ maximum of peak height were compared, and were found to be $13 \mathrm{~ms}, 11 \mathrm{~ms}$ and $10 \mathrm{~ms}$.

To evaluate the stability of droplet introduction, under the same conditions, the emission signal was measured at a frequency of $0.5 \mathrm{~Hz}$ for $20 \mathrm{~s}$. These results are shown in Fig. 7. Droplets were injected at low frequencies in order to stabilize the background signals arising from a droplet. The standard deviation of $\mathrm{Na}, \mathrm{Mg}$ and $\mathrm{Sr}$ was calculated at the peak height and for the peak area. The standard deviation calculated for the peak area was an improvement compared to that calculated for the peak height, which can be related to the scattering of droplets in plasma. Table 1 summarizes the detection limits (a) $\mathrm{Na} I 588.99 \mathrm{~nm}$

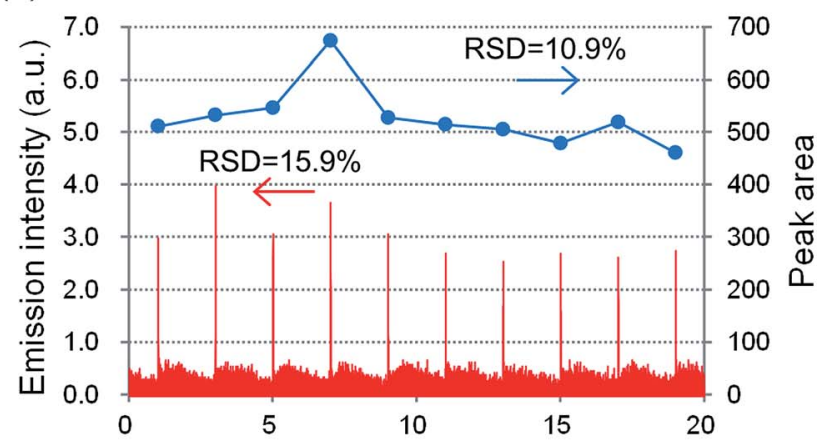

(b) $\mathrm{Mg} \| \mathrm{I} 280.27 \mathrm{~nm}$

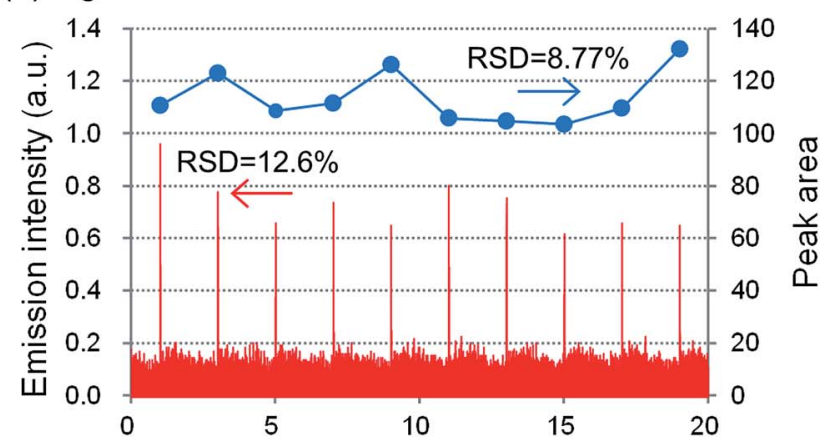

(c) $\mathrm{Sr}$ II $407.77 \mathrm{~nm}$

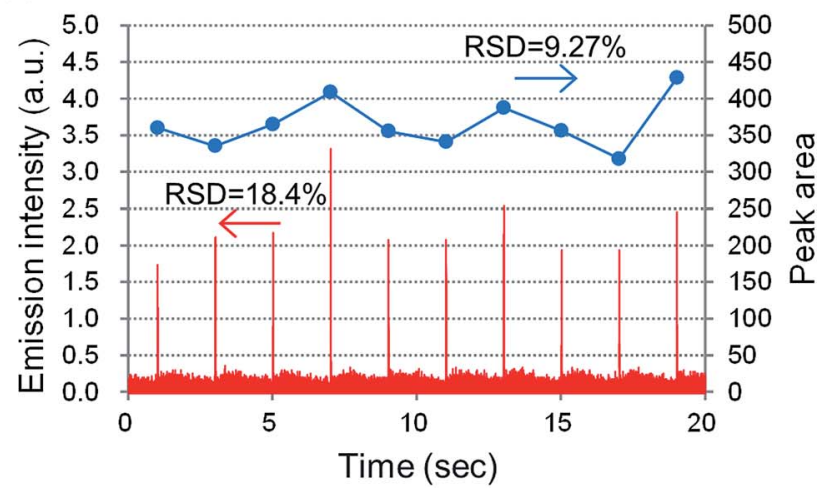

Fig. 7 Emission profiles of (a) $\mathrm{Na} \mid 588.99 \mathrm{~nm}$, (b) $\mathrm{Mg}|| 280.27 \mathrm{~nm}$, and (c) $\mathrm{Sr} \| \mathrm{I} 407.77 \mathrm{~nm}$, with injection of a series of droplets generated from $10 \mu \mathrm{g} \mathrm{mL}^{-1} \mathrm{Na}, \mathrm{Mg}$ and $\mathrm{Sr}$ standard solution. Emission intensities were observed by side-on observation (RF power, $700 \mathrm{~W}$; carrier gas flow, $0.4 \mathrm{~L} \mathrm{~min}{ }^{-1}$; droplet volume, $15 \mathrm{~nL}(300 \mu \mathrm{m})$; droplet introduction frequency, $0.5 \mathrm{~Hz}$ ).

and the absolute detection limits for $\mathrm{Na}, \mathrm{Mg}$ and $\mathrm{Sr}$. The $S / N$ was calculated from the peak area. The detection limit is defined as the concentration when the $S / N$ is 3 . The absolute detection limit (pg) was calculated by multiplying the detection limit ( $\mu \mathrm{g}$ $\mathrm{mL}^{-1}$ ) with the droplet volume $(\mathrm{nL})$. The detection limits of $\mathrm{Na}$, $\mathrm{Mg}$ and Sr were $20.3 \mathrm{pg}\left(1.35 \mu \mathrm{g} \mathrm{mL}^{-1}\right), 56.5 \mathrm{pg}\left(3.77 \mu \mathrm{g} \mathrm{mL}^{-1}\right)$ and $20.6 \mathrm{pg}\left(1.37 \mu \mathrm{g} \mathrm{mL} \mathrm{m}^{-1}\right)$, respectively. For comparison, detection limits in the ICP-AES equipped with a pneumatic nebulizer $^{30}$ are also listed in Table 1 . The absolute detection limit was calculated to be $500 \mathrm{pg}, 30 \mathrm{pg}$ and $30 \mathrm{pg}$ for an uptake

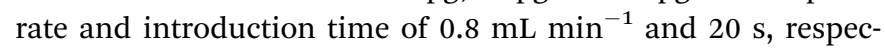
tively. When the D-DIN was used, the absolute detection limits 
Table 1 Comparison of the relative and absolute limit of detection (LOD) between the D-DIN-ICP-AES and conventional ICP-AES. The relative LOD calculated to be 3 times the $\operatorname{S} / \mathrm{N}(n=10)$. Absolute LODs were calculated by multiplying the detection limit ( $\left.\mu \mathrm{g} \mathrm{mL}^{-1}\right)$ with the droplet volume $(\mathrm{pL})\left(10 \mu \mathrm{g} \mathrm{mL}{ }^{-1} \mathrm{Na}, \mathrm{Mg}\right.$ and $\mathrm{Sr}$ standard solution; droplet volume, $15 \mathrm{~nL}(300 \mu \mathrm{m})$; emission intensities were observed by side-on observation)

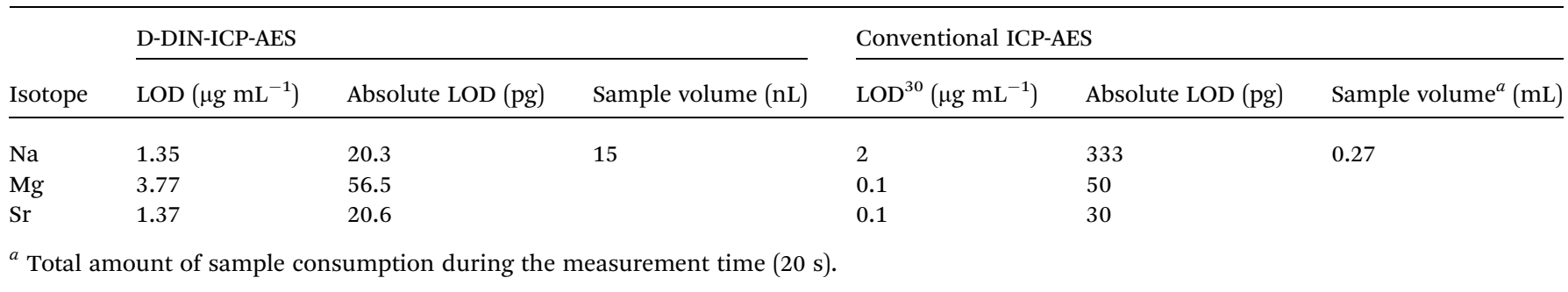

were almost at the same level when compared to a conventional nebulizer.

\section{Direct injection of yeast samples}

For direct injection of yeast cells by a single droplet, a droplet containing yeast cells was directly introduced into the plasma using a D-DIN. $0.44 \mathrm{~g}$ of dry yeast sample $\left(2.5 \times 10^{10}\right.$ cells per $\left.\mathrm{g}\right)$ was diluted with ultra-pure water, and the volume was adjusted to $50 \mathrm{~mL}$ (a dilution factor of 110). Yeast cell numbers in a single droplet were estimated from both the droplet volume and yeast cell numbers in the diluted yeast sample solution. In the case of $15 \mathrm{~nL}$ of droplet volume, yeast cell numbers in a single droplet correspond approximately to 3300 yeast cells. These results are shown in Fig. 8. The emission intensity of Na was measured in a single droplet containing yeast cells. To estimate the quantity of elements in a single droplet, digestion of the dry yeast sample was carried out after $\mathrm{HNO}_{3}$ and $\mathrm{H}_{2} \mathrm{O}_{2}$ were added. The digested samples were analysed by ICP-MS. The concentration and amount of $\mathrm{Na}$ in cells were $961 \pm 77 \mu \mathrm{g} \mathrm{mL} \mathrm{m}^{-1}$ and $37.9 \pm 3.0 \mathrm{fg}$, respectively. The total amount of elements in a single yeast cell was calculated by dividing the concentration of elements in a single yeast cell by the yeast cell number/dry weight of yeast. From these results, the concentration of $\mathrm{Na}$ in a droplet containing 3300 yeast cells was calculated to be $8.4 \mu \mathrm{g} \mathrm{mL}^{-1}$ if it is assumed that all of the cells are the same. Thus, in the case of a

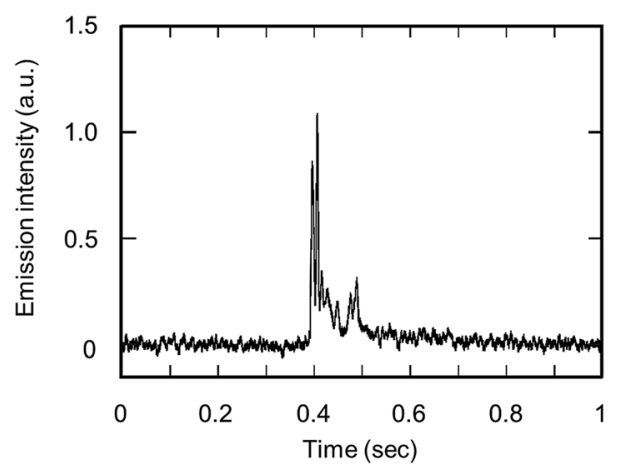

Fig. 8 Emission intensities of $\mathrm{Na}$ I $588.99 \mathrm{~nm}$ from a single droplet containing 3300 yeast cells. Emission intensities were observed by side-on observation (RF power, $700 \mathrm{~W}$; carrier gas flow, $0.4 \mathrm{~L} \mathrm{~min}{ }^{-1}$; droplet volume, $15 \mathrm{~nL}(300 \mu \mathrm{m}))$.
$15 \mathrm{~nL}$-droplet volume, the absolute amount of Na corresponds to $125 \mathrm{pg}$. With the single shot injection of sample droplets containing yeast cells, a strong sodium emission was observed with sufficient $S / N$. These results were almost comparable to the signal intensity of these elements as measured by direct injection of yeast cells.

\section{Conclusions}

To enable the highly sensitive analysis of the cell suspension, we developed a D-DIN system. The volume of the droplets was controlled by the nozzle tip diameter and the applied back pressure. Using this system, the droplet volume was changed from $700 \mathrm{pL}(110 \mu \mathrm{m})$ to $100 \mathrm{~nL}(580 \mu \mathrm{m})$. The droplet velocity can be controlled from 0.55 to $16 \mathrm{~m} \mathrm{~s}^{-1}$ with a corresponding increase in back pressure. For a single droplet with a $15 \mathrm{~nL}$ volume, the absolute detection limits of $\mathrm{Na}, \mathrm{Mg}$ and Sr were 20.3 pg, $56.5 \mathrm{pg}$ and $20.6 \mathrm{pg}$, respectively. Furthermore, a droplet containing yeast cells was directly introduced into the plasma. With a single shot droplet that included about 3300 yeast cells, a mass signal of $\mathrm{Na}$ was observed. However, its detection sensitivity was not found to be sufficient for the detection of trace elements (ppb level) in a single cell. To improve the detection sensitivity, the solvent load should be reduced by desolvation. Therefore, we currently developed an injection gas heating system. The operation conditions according to the droplet size would be optimized. Also we would apply the D-DIN system to ICP-MS.

\section{Acknowledgements}

The present research, entitled "World's First Direct Single Cell Analysis using Inductively Coupled Plasma Mass Spectrometer", was supported by Agilent Technologies Foundation Research Project Gift. We are grateful to Dr Takashi Kondo (Agilent Technologies) for providing valuable information about instrumental and operational details of the ICP ion source. The present research was also supported by a research fellow of the Japan Society for the promotion of young scientists at the Japan Society for the Promotion of Science (JSPS). We thankfully acknowledge many fruitful discussions with Dr Norbert Jakubowski (BAM Federal Institute for Materials Research and Testing). 


\section{Notes and references}

1 L. A. Finney and T. V. O'Halloran, Science, 2003, 300, 931.

2 H. Haraguchi, J. Anal. At. Spectrom., 2004, 19, 5.

3 K. H. Thompson and C. Orvig, Science, 2003, 300, 936.

$4 \mathrm{H}$. Haraguchi, A. Ishii, T. Hasegawa, H. Matsuura and T. Umemura, Pure Appl. Chem., 2008, 80, 2595.

5 D. R. Bandura, V. I. Baranov, O. I. Ornatsky, A. Antonov, R. Kinach, X. Lou, S. Pavlov, S. Vorobiev, J. E. Dick and S. D. Tanner, Anal. Chem., 2009, 81, 6813.

6 S. C. Bendall, E. F. Simonds, P. Qui, E. D. Amir, P. O. Krutzik, R. Finck, R. V. Bruggner, R. Melamed, A. Trejo, O. Ornatsky, R. S. Balderas, S. K. Plevritis, K. Sachs, D. Pe'er, S. D. Tanner and G. P. Nolan, Science, 2011, 332, 687.

7 F. Li, D. W. Armstrong and R. S. Houk, Anal. Chem., 2005, 77, 1407.

8 K. S. Ho and W. T. Chan, J. Anal. At. Spectrom., 2010, 25, 1114.

9 A. S. Groombridge, S. Miyashita, S. Fujii, K. Nagasawa, T. Kahashi, M. Ohata, T. Umemura, A. Takatsu, K. Inagaki and K. Chiba, Anal. Sci., 2013, 29, 597.

10 F. Laborda, J. Jiménez-Lamana, E. Bolea and J. R. Castillo, J. Anal. At. Spectrom., 2013, 28, 1220.

11 G. M. Hieftje and H. V. Malmstadt, Anal. Chem., 1968, 40, 1860.

12 J. B. French, B. Etkin and R. Jong, Anal. Chem., 1994, 66, 685. 13 J. W. Olesik and S. E. Hobbs, Anal. Chem., 1994, 66, 3371.

14 S. Groh, C. C. Garcia, A. Murtazin, V. Horvatic and K. Niemax, Spectrochim. Acta, Part B, 2009, 64, 247.

15 J. O. O. v. Niessen, J. N. Schaper, J. H. Petersen and N. Bings, J. Anal. At. Spectrom., 2011, 26, 1781.

16 K. Shigeta, H. Traub, U. Panne, A. Okino, L. Rottmann and N. Jakubowski, J. Anal. At. Spectrom., 2013, 28, 646.
17 K. Shigeta, G. Koellensperger, E. Rampler, H. Traub, L. Rottmann, U. Panne, A. Okino and N. Jakubowski, J. Anal. At. Spectrom., 2013, 28, 637.

18 S. Gschwind, L. Flamigni, J. Koch, O. Borovinskaya, S. Groh, K. Niemax and D. Gunther, J. Anal. At. Spectrom., 2011, 26, 1166.

19 B. Franze, I. Strenge and C. Engelhard, J. Anal. At. Spectrom., 2012, 27, 1074.

20 A. Okino, H. Miyahara and G. Ohba, EP 1895286 A1, 2008, US 2009/0297406, 2009.

21 H. Miyahara, K. Shigeta, N. Nakashima, Y. Nagata and A. Okino, Jpn. Anal., 2010, 59, 363.

22 H. Yabuta, H. Miyahara, M. Watanabe, E. Hotta and A. Okino, J. Anal. At. Spectrom., 2002, 17, 1090.

23 A. Okino, H. Miyahara, H. Yabuta, M. Watanabe and E. Hotta, in Colloquium Spectroscopicum Internationale XXXIII, 2003, pp. 696-697.

24 H. Miyahara, T. Doi, Y. Mizusawa, Y. Hayashi, E. Hotta and A. Okino, in 2004 Winter Conference Plasma Spectrochemistry, 2004, p. 284.

25 H. Miyahara, T. Doi, Y. Mizusawa, E. Hotta and A. Okino, Jpn. Anal., 2004, 53, 817.

26 A. Montaser, I. Ishii, R. H. Clifford, S. A. Sinex and S. G. Capar, Anal. Chem., 1989, 61, 2589.

27 R. C. Weast, CRC Handbook of Chemistry and Physics, CRC Press, Inc, Florida, 1989.

28 L. Ebdon and P. Goodall, J. Anal. At. Spectrom., 1992, 7, 1111. 29 Y. Kaburaki, A. Namura, Y. Ishihara, T. Iwai, H. Miyahara and A. Okino, Anal. Sci., 2013, 29, 1147.

$30 \mathrm{H}$. Haraguchi, Basis and Application of ICP Optical Emission Spectrometry, Koudansha, Tokyo, 1986. 